\title{
Carbon Footprint of Semi-Mechanical Sago Starch Production
}

\author{
Mega Ayu Yusuf ${ }^{12^{*}}$, Muhammad Romli', Suprihatin', Edi Iswanto Wiloso ${ }^{3}$ \\ 1 Department of Agroindustrial Technology, Bogor Agricultural University (IPB), Bogor 16680, Indonesia \\ 2 Department of Agricultural Engineering, University of Musamus, Merauke 99616, Indonesia \\ 3 Research Center for Chemistry, Indonesian Institute of Sciences (LIPI), Tangerang Selatan 15314, Indonesia \\ * Corresponding author's e-mail: yusuf@unmus.ac.id;, megaayu.yusuf@gmail.com
}

\begin{abstract}
Indonesia is the country with the greatest potential for sago in the world. This research is intended to determine the carbon footprint of sago starch produced from a semi-mechanical process. The calculation was carried out using the LCA approach with the system boundary of cradle to gate. The process steps were carried out in a combination of manual work and diesel-driven engines. The inventory data on material, energy input flows and emissions were obtained from 3 samples of typical medium-scale semi-mechanical sago mills. It was found that the carbon footprint of the sago produced from semi-mechanical processes was $37.9 \pm 0.6 \mathrm{kgCO}_{2}$ eq per 1 ton of dried sago starch. Further analysis shows that $62 \%$ of the carbon footprint comes from the extraction stage and $38 \%$ from the transportation. It can be estimated that the amount of greenhouse gas emissions from the semi-mechanical sago starch production in Indonesia for 2018 reached around 2,617,639 $\mathrm{kg} \mathrm{CO}_{2}$ eq.
\end{abstract}

Keywords: green house gases, carbon footprint, life cycle assessment, sago starch

\section{INTRODUCTION}

Indonesia is the largest owner of sago plant with an area of around 1128 million hectares or $51 \%$ of the world's sago area. The area is spread in 183 districts from 27 provinces. The productivity of this very important food crop can reach 25 tons of dry starch/ha.year, the highest compared to other starch-producing plants such as cassava and potatoes which are 10-15 tons of dried starch/ ha.year [1]. The total sago starch produced by Indonesia can reach 6.84 million tons/year [2]. The sago starch contains $94-96 \%$ of carbohydrates, higher than that in rice which only contains $80.4 \%$, corn $71.7 \%$, and potatoes $16.3 \%$ [3]. The high sago potential can drive the development of sago-based agroindustry in Indonesia.

Even though the development of the sago flour industry can make a positive contribution to income, anticipating the negative impact on the environment also needs to be done. The Indonesian government's strategic plan for 2017 through the Ministry of Environment, recommends that all industrial products be analyzed for carbon footprint throughout their life cycle [4]. The research on the carbon footprint and water footprint associated with starch and starch products has been done quite a lot, for example pertaining to the use of starch as a raw material for bioethanol for energy sources. However, this research is generally carried out on the starch derived from cassava, corn and potatoes. A similar research, albeit using the LCA approach to calculate the carbon footprint of sago starch products and their derivatives, is still very limited.

The sago starch production can cause various environmental impacts such as global warming potential due to the changes in land use, energy use, water use, or because of the formation of liquid and solid waste from the extraction and refining process of sago starch. Along with the concerns about the increasing danger of climate change, the industry has become curious about the extent to which their products contribute to these emissions. Furthermore, the downstream industry, which uses sago starch as a raw material 
for its downstream products, also needs information about this carbon footprint to determine the impact of their products on the environment.

Therefore, the carbon footprint as a measure of the environmental impact related to the sago starch products needs to be determined. This will be the basis for evaluating the environmental performance of sago starch products and theirderivatives.

The research works on sago generally only focus on the aspects of cultivation and only a few address the environmental impact at the industrial stage. Particularly, there is no comprehensive research that determines the carbon footprint of sago products starting from harvesting to the extraction process to obtain sago starch. Therefore, this study was conducted to determine the carbon footprint of sago starch produced by semi-mechanical processing using the LCA approach. The data was collected from three medium-scale sago mills in Bogor, West Java. The semi-mechanical process was chosen in this study because $55 \%$ of sago starch production in Indonesia, mainly in Riau, West Java, and most of Sulawesi and Papua use this type of semi-mechanical process [5]. The results of this study can be used to identify the hotspots or sources of environmental load at each stage of the product life cycle, so that it is useful for policy makers to make decisions pertaining to improving the environmental performance of the products.

\section{MATERIALS AND METHODS}

According to ISO 14040 standards, the LCA study has four phases, namely, (1) determination of goal and scope, (2) life cycle inventory analysis, (3) impact assessment and (4) interpretation [6].

\section{Goal and scope of the study}

Life cycle assessment (LCA) is a method for estimating the environmental impacts of a product or service in the entire supply chain [7]. In this study, the environmental impact of sago starch product is limited only to global warming which is carried out through the analysis of carbon footprint. At present, the analysis of carbon footprint has become one of the main indicators of environmental protection [8]. Carbon footprint is defined as the total amount of greenhouse gas emissions, both directly and indirectly generated by all activities in a predetermined system boundary [9].
The goal of this study was to determine the carbon footprint and evaluate the impact of global warming caused by the sago starch produced from 3 medium-scale semi-mechanical process of sago mills. The ISO 14040/44 guideline on Carbon Footprint Calculation for Products in accordance with the LCA methodology based on IPCC 2007 [10] was used for the impact assessment.

\section{Functional unit and system boundary}

The calculation of carbon footprint is based on a functional unit, which is the measure of the system function that informs the reference unit related to the research inventory data [11]. In this study, 1 ton of dried sago starch with a moisture content of $13 \%$ was the functional unit chosen.

The system boundary of product life cycle is limited to harvesting of sago trees from the forest, handling of raw materials, transporting sago stems to the mills, and extracting the starch from sago stem, often referred to as "cradle to gate". The process flow diagram of semi-mechanical sago starch production is shown in Figure 1.

\section{Life Cycle Inventory}

Life cycle inventory is an inventory of the input and output data from the system boundaries that have been made. As mentioned before, the inventory analysis was based on the data collected from three medium-scale semi-mechanical process of sago mills (X, Y, and Z) located in the North and East Bogor sub-districts, West Java province. The three mills were selected because they use raw materials originating from the same forest located in Bayah, Banten province and produce dried sago starch with the same technology. The number of working days is 24 days/month. The selling price of dried sago starch ranges from Rp. 6000 to Rp. 6500 per $\mathrm{kg}$ for bulk purchases and Rp. 10000 per $\mathrm{kg}$ for retail. The general profile of the medium-scale sago starch mills is given in Table 1 .

In general, there are 3 types of sago starch processing in Indonesia, namely traditional, semimechanical and mechanical processes. In principle, they share common flow process, except for the use of tools and machines in several process steps. In the traditional process, sago is processed completely manually. In semi-mechanical processes, a combination of manual and mechanical processes is used. In mechanical processes, 


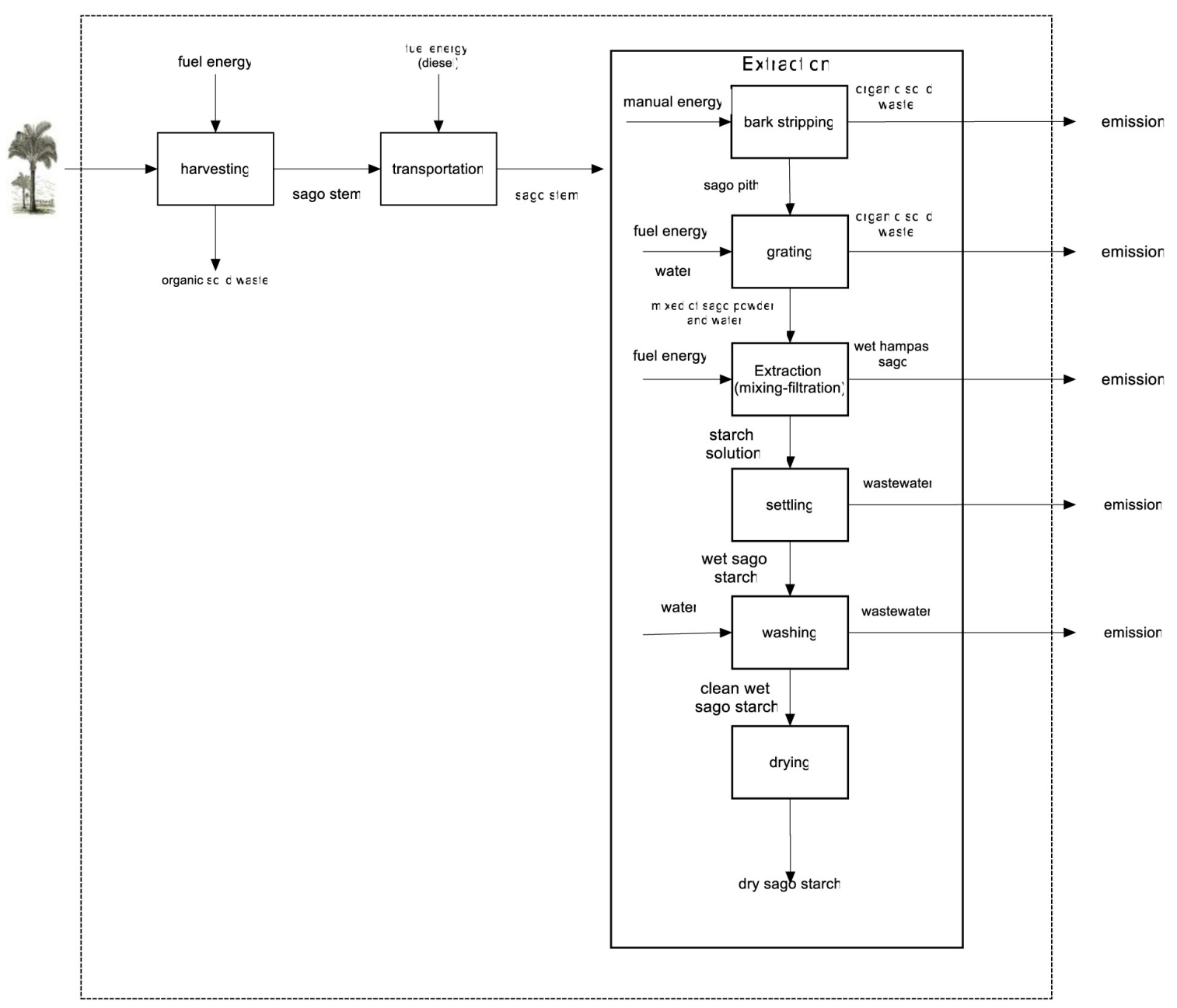

Fig. 1. Flow process diagram of semi-mechanical sago starch processing

almost all process stages involve the use of machines. The following paragraphs briefly describe the sago starch production process as a basis for the life cycle inventory analysis.

The semi-mechanical process of sago starch production begins with the cutting of sago trees in the forest using chainsaws. The highest starch content, of about $41 \%$ according to Pei Lang et al. [12], occurs during the growth of young sago that is around 12.5-13 years old, when the plants are going to flower. The starch content will decrease when the plants are flowering or afterwards. According to the farmers, the highest starch content occurs when the shoots of the sago trees are shaped hand-like and widen. After removing the unused parts, the stem is then cut into $0.5-1$ meter sizes using chainsaws and immediately sent to the sago mills on the same day to prevent the yield loss of starch. Transportation to the mills is carried out using a 6-wheeled pickup truck.

At the mill, the stem is chopped into 4 pieces using axes and peeled to remove the bark. Wastes are generated and also a partial loss of starch occurs at this stage. Grating is carried out with a cylindrical type grater machine of $600 \mathrm{~kg} /$ hour capacity driven by a $12 \mathrm{HP}$ diesel engine to disrupt the stem. The diesel engine works for 13 hours per 7 tons sago stem processed and consumes 15 liters of fuel. Here, splatter is wasted from the machine since it is not equipped with a lid. The

Table 1. Profile of medium-scale semi-mechanical process of sago mills

\begin{tabular}{|c|c|c|c|c|}
\hline Mill/Location & Number worker & Product & $\begin{array}{c}\text { Production capacity } \\
\text { (ton/month) }\end{array}$ & $\begin{array}{c}\text { Number of working } \\
\text { day/month }\end{array}$ \\
\hline $\begin{array}{l}\text { X / East Bogor } \\
\text { Y / North Bogor } \\
\text { Z / North Bogor }\end{array}$ & $\begin{array}{l}3 \\
4 \\
3\end{array}$ & $\begin{array}{l}\text { Dried starch } \\
\text { Dried starch } \\
\text { Dried starch }\end{array}$ & $\begin{array}{l}16-18 \\
17-18 \\
18-20\end{array}$ & $\begin{array}{l}24 \\
24 \\
24\end{array}$ \\
\hline
\end{tabular}


grated materials are mixed with water and mechanically agitated in a tank to extract the starch from the cell tissue and followed by filtration to separate the pulp from the starch solution. The filter screen moves back and forth in a sifting motion while water is sprayed on the grated material so that the starch solution passes down through the filter and the pulp remains detained on the filter. The filter screen is run by a diesel engine with the fuel consumption of 151 per 13 hours. The starch solution goes into the settling basin through PVC pipes. The waste formed at this stage is wet sago pulp. Starch settling is carried out in 6 settling tanks arranged in series. Each tank has a hole at the top that serves to channel the starch solution from one tank to another. When the starch solution passes through a tank, the starch will be held back and accumulate at the bottom of the tank. The starch-free supernatant is discharged through a channel to the river around the factory area. This liquid waste contains soluble organics [13]; therefore, when it is disposed without treatment can deplete the dissolved oxygen of the water body [14]. Cleansing is done by flowing water to wash the upper layer of accumulated sago from the sap, mud and other impurities. The washed starch is manually cut into a square shape, lifted by hand and moved to the draining area. Wet sago is left to drain overnight to reduce the water content before drying. The drained sago is leveled on a bamboo tray until evenly distributed and then sundried for 6-8 hours depending on the weather. The dried starch is brought to the storage room after manual sieving at 100 mesh, packed in a $15 \mathrm{~kg}$ polypropylene bag and ready to be marketed.

\section{Data collection}

In the stage of life cycle inventory, the data related to material and energy entering the system and emissions leaving the system were collected.
Sago trees are considered as inputs from nature, and in this case, standing tree (soft) data taken from SIMAPRO were used. SIMAPRO software (version 8.5.0.0) and database from ECOINVENT (version 3.3) were used to help analyze this inventory. The inventory data related to harvesting and raw materials handling, transportation, and extraction process were obtained from interviews and direct measurements. The characterization of effluent was conducted only in mill X, and it is assumed that the other mills have similar effluent characteristics. A summary of the types and methods of data collection for the life cycle inventory is shown in Table 2.

\section{Allocation method}

The allocation methods need to be specified when two or more products share the same production process. In this sago process, besides starch as the main product, sago pulp is also produced as a by-product. In this study, sago pulp was categorized as a co-product or by-product with economic value, and the allocation method was based on mass allocation. This study does not perform a sensitivity analysis on different allocation methods.

\section{Impact category and characterization}

For assessment purposes, the global warming impact caused by greenhouse gases will be analyzed from the life cycle inventory (LCI). The determination of carbon footprint $\left(\mathrm{CO}_{2}\right.$ eq $)$ was based on the generation of $\mathrm{CO}_{2}, \mathrm{CH}_{4}$ and $\mathrm{N}_{2} \mathrm{O}$. The standard ratios of methane and nitrous oxide relative to carbon dioxide, based on Global Warming Potential over a period of one hundred years of 25 and 298 were used, respectively. Total

Table 2. Data sources of life cycle inventory

\begin{tabular}{|l|l|l|}
\hline \multicolumn{1}{|c|}{ Life cycle stage } & \multicolumn{1}{|c|}{ Data } & \multicolumn{1}{c|}{ Data source and collecting method } \\
\hline Harvesting and handling & Material and wastes & Measured \\
& Diesel fuel & Sago farmers; interview \\
Woods (soft)/unspecified, standing/kg & Data from Simapro \\
Fype of vehicle and distance & Factory manager; interview \\
Fransportation & Fiesel fuel & Measured \\
Processing & Materials and wastes & Mactory manager; interview \\
& Diesel fuel & Factory manager; interview \\
& Fuel oil & Measured \\
& Water & Data from Simapro \\
\hline
\end{tabular}


greenhouse gas emissions expressed as $\mathrm{kg} \mathrm{CO}_{2}$ eq are determined as:

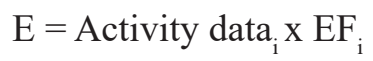

where $: E=$ Emission

Activity data $_{i}=$ life cycle inventory value of $i$, unit

$E F_{i}=$ emission factor of $\mathrm{i}, \mathrm{kg} \mathrm{CO}_{2} \mathrm{eq} / \mathrm{unit}$

The emission factors used in this study were mostly taken from IPCC 2007. The data not found in IPCC 2007 were taken from ecoinvent databases and other international data providers contained in the SIMAPRO library, for example background data of the sago tree. In addition, the calculation of the emissions caused by the production process and the resulting waste was carried out using the SIMAPRO calculation method. The emission factors are shown in Table 3.

\section{RESULTS AND DISCUSSIONS}

\section{Characteristics of Sago Starch}

Sago starch is a nutritional polysaccharide which mainly composed of $27 \%$ amylose and $73 \%$ of amylopectin [15]. Amylose is a straight chain polymer of glucose, whereas amylopectin is a branched chain polymer of glucose. Sago starch has an average granule size of $30 \mu \mathrm{m}, 70^{\circ} \mathrm{C}$ gelatinization temperature, $15-17 \mathrm{~J} / \mathrm{g}$ enthalpy gelatinization, and type $\mathrm{C}$ in diffraction X-ray pattern [16].

Table 3. Emission factors

\begin{tabular}{|l|c|c|c|}
\hline \multicolumn{1}{|c|}{ Source } & Unit & $\mathrm{kgCO}_{2 \mathrm{eq}} / \mathrm{unit}$ & Ref. \\
\hline Diesel fuel & $\mathrm{kg}$ & 0.3282 & {$[5]$} \\
Fuel oil & $\mathrm{kg}$ & 0.3057 & {$[16]$} \\
Transportations; & & & \\
Six-wheel 11-ton truck & & & \\
$\quad$ Full load & $\mathrm{tkm}$ & 0.0610 & {$[21]$} \\
$\quad$ No load & $\mathrm{tkm}$ & 0.4892 & {$[21]$} \\
\hline
\end{tabular}

\section{Life cycle inventory of sago starch}

The environmental impacts of sago products start from the harvesting of sago trees originating from the forest. Tree felling is done by using diesel-fueled chainsaws. The sago stem is then sent to the extraction site. Transportation is carried out using diesel fuel trucks with an average capacity of 11 tons. The diesel fuel consumption is calculated based on the standard unit of diesel fuel consumption per $\mathrm{km}$ mileage (IPCC 2006). At the sago mill, the sago stems undergo a series of processes ranging from cutting, stripping hard skin, grating, mixing-filtration, settling, washing and drying. In this starch extraction stage, the environmental impacts include the use of diesel fuel to operate generator sets, use of engine lubricants, and solid and liquid wastes generation.

The inventory results from this cradle to gate system of three medium-scale semi-mechanical process of sago starch mills are shown in Table 4. The table also compares the results of this study with the life cycle inventory of sago starch produced by the traditional process conducted from the previous study and cassava starch.

\section{Starch yield}

The results of the inventory analysis on the three semi-mechanical sago mills showed an almost uniform performance in terms of starch yield. This is because the three mills use the same process flow and type of machinery. When compared with the traditional extraction of sago starch, this semi-mechanical process is more efficient. In the traditional process, the starch yield is $10.3 \%$, whereas in the semi-mechanical process is $14.3 \%$.

\section{Water consumption}

The use of water in the semi-mechanical process is far greater than that in the traditional

Table 4. Life cycle inventory of 1 ton sago starch (cradle to gate) vs 1 ton cassava starch

\begin{tabular}{|l|c|c|c|c|c|}
\hline \multirow{2}{*}{ Source } & \multicolumn{2}{|c|}{ Semi-Mechanical Sago Process } & \multirow{2}{*}{ Traditional process } & \multirow{2}{*}{ Cassava starch [17] } \\
\cline { 2 - 4 } & $\mathrm{X}$ & $\mathrm{Y}$ & $\mathrm{Z}$ & 9750 & $3,930-4,490$ \\
\hline Stem $(\mathrm{kg})$ & 7,115 & 6,900 & 7,000 & 4.7 & $6.7-29.3$ \\
Water $\left(\mathrm{m}^{3}\right)$ & 17.75 & 17.60 & 18.50 & - & 2.64 \\
Diesel Fuel $(\mathrm{kg})$ & 53.28 & 51.13 & 49.14 & - & $23.07-38.33$ \\
Fuel oil $(\mathrm{kg})$ & 0.36 & 0.36 & 0.36 & 15800 & - \\
Pulp (kg) & 17315 & 17100 & 17250 & 45.12 & 124.2 \\
C from pulp & 53.0 & 47.6 & 52.10 & 0.07 & 881.4 \\
N from pulp & 0.1 & 0.09 & 0.13 & ND & 0.79 \\
P from pulp & ND & ND & ND & & \\
\hline
\end{tabular}


process. As shown in Table 5, the average water consumption in semi-mechanical process is $18 \mathrm{~m}^{3} /$ ton starch, whereas that in traditional process is only $4.7 \mathrm{~m}^{3} /$ ton starch. The difference in the scale of production and the number of process stages, namely mixing and washing in the semi-mechanical process, is thought to be the cause. The water consumption of the semi-mechanical sago process is, however, comparable with that of cassava starch and still within the range of the reported values of $6.7-29.3 \mathrm{~m}^{3} /$ ton cassava starch [18].

\section{Diesel fuel and fuel oil consumption}

The average use of diesel fuel for mills $X$, $\mathrm{Y}$ and $\mathrm{Z}$ is $53.28,51.13$ and $49.14 \mathrm{~kg} / \mathrm{ton}$ starch, respectively. The high diesel fuel consumption characterizes the process of grating \& mixing and transportation. The relatively higher consumption of diesel fuel in mill $\mathrm{X}$ is caused by the longer distance from the forest to the mill site. The total consumption of diesel fuel and fuel oil in semimechanical sago process is $51.5 \mathrm{~kg} /$ ton starch in average. This value is higher compared to the diesel fuel and fuel oil in cassava processing which is $25.7-41 \mathrm{~kg} /$ ton starch.

\section{Wastes generation}

As shown in Table 5 for solid waste in the form of pulp, both the quantity and composition of $\mathrm{C}, \mathrm{N}$ and $\mathrm{P}$ are comparable between the semimechanical and traditional processes. Table 5 shows that the effluent characteristics in general exceed the regulatory limit. The organics content expressed in BOD and COD is, however, much lower than that reported for cassava effluent.

\section{Carbon footprint}

The carbon footprint of sago starch product from semi-mechanical process was calculated based on the life cycle inventory (Figure 2). The values of carbon footprint of mills $\mathrm{X}, \mathrm{Y}$ and $\mathrm{Z}$ are comparable, namely 38083,37293 and $38566 \mathrm{~kg} \mathrm{CO}$ eq/ton of sago starch, respectively. The three mills give an average value of $38 \mathrm{~kg}$ $\mathrm{CO}_{2}$ eq/ton of sago starch. This value is lower than that of traditional process which is $17.9 \mathrm{kgCO}_{2}$ eq. The need for longer distance transportation and also the use of energy intensive machinery led to the higher value of carbon footprint of semimechanical sago process.

Table 5. Effluent characteristics of sago mill

\begin{tabular}{|l|c|c|c|}
\hline \multicolumn{1}{|c|}{ Parameter } & A & B & C \\
pH & (Mill X) & {$[21]$} & (Regulatory limit KEP-02/MENLH/1998) \\
BOD (mg/L) & 5.4 & 4.8 & $6-9$ \\
COD (mg/L) & 188 & 531 & 150 \\
Cyanide (mg/L) & 221 & 2080 & $100-300$ \\
TSS $(\mathrm{mg} / \mathrm{L})$ & 0.008 & - & 0,5 \\
Volume $(\mathrm{kg} / 7$ ton sago stem) & 532 & - & 150 \\
\hline
\end{tabular}

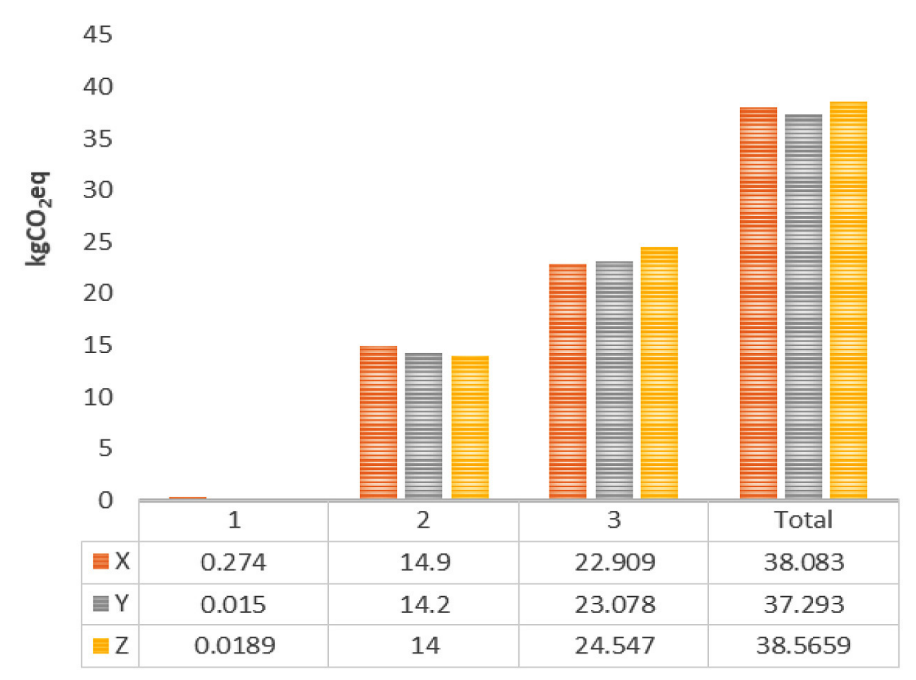

Fig. 2. The carbon footprint results. 1) Harvesting 2) Transportation 3) Extraction 
The carbon footprint of a semi-mechanical sago product is much lower compared to the reported carbon footprints of corn starch, potato starch, and cassava starch which are $315 \mathrm{~kg} \mathrm{CO}$ eq/ton [19], $314 \mathrm{~kg} \mathrm{CO}_{2}$ eq/ton [20], and $292 \mathrm{~kg} \mathrm{CO}$ eq/ton [21], respectively (Figure 3). Even though the diesel fuel input is lesser in the cassava processing (Table 5), large quantities of lubricant are used in the extraction of cassava starch. Cassava processing also uses a considerable amount of electricity and heat from natural gas which causes high emissions. This electricity and heat are used in many machines such as root washer, root cutter, rasper, coarse extractor, separator, flash dryer and cyclone and cooling cyclone. Similarly, in the production of potato and corn starch, electricity and heat from natural gas is also used in the washing process, fiber sieving, fiber dewatering and hydro cyclone starch refining. The higher content of $\mathrm{C}, \mathrm{N}$ and $\mathrm{P}$ on cassava pulp may also contribute to the higher carbon footprint of cassava starch.

This research work shows that the use of diesel fuel and fuel oil highly contributes to the total carbon footprint of sago product. In mill X, material transportation contributes $39 \%$ and the starch extraction process $60 \%$. In mill $\mathrm{Y}$, transportation contributes $38 \%$ and extraction of $62 \%$ of total carbon footprint. In mill $\mathrm{Z}$, the contributions of transportation and extraction are $36 \%$ and $64 \%$, respectively. Overall, as Figure 2 indicates, the starch extraction stage and material transportation, contribute $62 \%$ and $38 \%$ to the total carbon footprint of sago starch product, respectively.

From the results of this study it can be estimated the magnitude of the effect of greenhouse gases caused by mid-scale semi-mechanical sago production in Indonesia. On the basis of the average value of carbon emissions from sago starch products of $37.9 \mathrm{~kg} \mathrm{CO} 2 \mathrm{eq} / \mathrm{ton}$ of sago starch and annual sago starch production from semi-mechanical processes in Indonesia amounting to 69,067 tons, the total carbon footprint of sago starch with a semi-process mechanical in Indonesia is estimated at $2,617,639 \mathrm{~kg} \mathrm{CO}_{2}$ eq.

\section{CONCLUSIONS}

The average value of the carbon footprint of the sago starch products obtained by the semimechanical process of the three sago mills is $37.9 \pm 0.6 \mathrm{~kg} \mathrm{CO}$ eq. The value of this carbon footprint mostly comes from the extraction process of starch, which is equal to $62 \%$, then from transportation of materials, which is $38 \%$. The stage of harvesting sago plants in the forest does not have a significant impact. The significant contribution of GHG emissions comes from the use of diesel fuel and fuel oil to operate machinery in the starch extraction process and to operate transportation vehicles. The carbon footprint value of this semi-mechanical sago starch product is higher than the value for starch products derived from traditional processes that rely on manual labor, namely $17.9 \mathrm{kgCO}_{2}$ eq. However, the value is much higher when compared to the carbon footprint of other similar starch products, such as potato starch, which is $314 \mathrm{~kg} \mathrm{CO}$ eq, corn starch which is $315 \mathrm{~kg} \mathrm{CO}_{2}$ eq and cassava starch which is $292 \mathrm{~kg} \mathrm{CO}$ eq. This is mainly because the process of producing potato starch, corn starch and cassava starch involves the use of electricity- and natural gas-based energy. From the results of this study, it can be estimated that the total greenhouse gas impact produced from the semi-mechanical sago starch production in Indonesia for one year

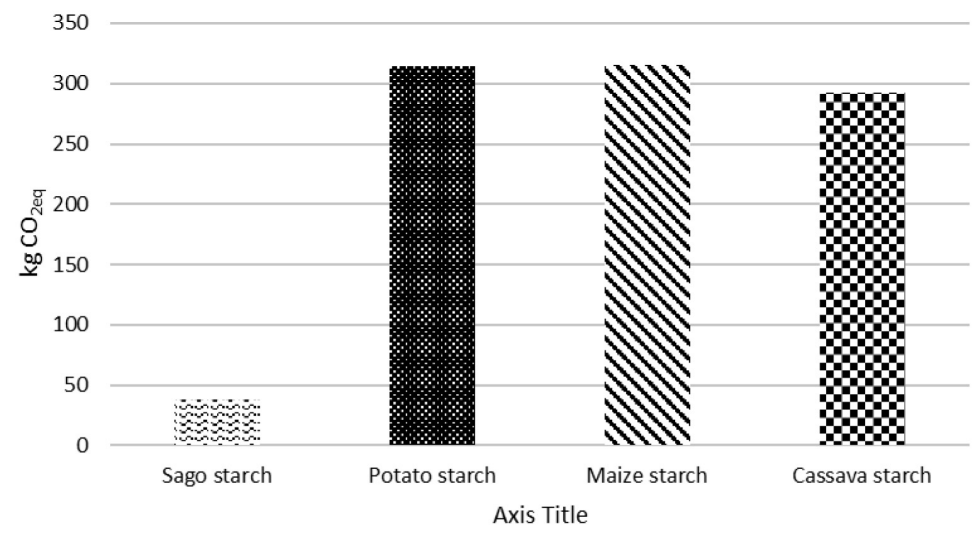

Fig. 3. Comparison of the life cycle carbon footprint values of several types of starch products 
(2018) are around 2,617,639 $\mathrm{kg} \mathrm{CO}_{2}$ eq. This research work to calculate the carbon footprint of the sago starch products produced in a full mechanical process is still ongoing.

\section{REFERENCES}

1. Bantacut T. 2011. Sago: Resource for Main Food Diversification. PANGAN, Vol. 20, No. 1, March, $27-40$

2. Syakir M and Elna . 2013. Potential of Sago Plants (Metroxylon sp.) As Bioenergy Raw Materials. Perspektif 12(2), 57-64.

3. Ni'mah S, Achmad R, Heru S. 2013. Design of Sago Flour Processing Plant, Pomits Engineering Journal 2(1), 1-3

4. Nugraha AZ, Yani M, Wiloso EI. 2017. Life Cycle Assessment (LCA) of Cement Products at PT. Indocement Tunggal Prakarsa. Thesis : Institut Pertanian Bogor. Bogor.

5. Directorate General of Plantation. 2017. Statistics of plantations in Indonesia for sago commodities 2015-2017. Secretariat of the directorate general of Indonesian plantations

6. International Standards Organization (ISO), 2006. Environmental management-Life Cycle Assessment-Principles and framework, ISO14040, BSI, CEN

7. UNEP 2007. Life cycle management-A business guide to sustainability, United National Environmental Programme, Geneva

8. Cuce L, Klemes JJ, Kravanja Z, 2012. A review of footprint analysis tools for monitoring impacts on sustainability. J of Cleaner Production, 34, 9-12.

9. International Standards Organization (ISO), 2008. Environmental management-Life Cycle Assessment-Principles and framework, ISO14040, BSI, CEN.

10. International Standards Organization (ISO), 2008. Environmental management-Life Cycle Assessment-Principles and framework, ISO14040, BSI, CEN.
11. UNEP 2007. Life cycle management-A business guide to sustainability, United National Environmental Programme, Geneva

12. Pei-Lang, A.T., A.M.D. Mohamed and A.A. Karim. 2005. Sago Starch and Composition of Associated Components in Palms of Different Growth Stages. Carbohydrate Polymers 63 (2006) 283-286

13. Saifuddin D. 2000. Design of Advanced Sago Starch Processing Plant Using SLP. [Thesis].Bogor(ID). InstitutPertanianBogor

14. Anbukumar S, Prasad NM, Kumar MA. 2014. Effluent Treatment for Sago Industry Using Zeolite and Active Carbon. Open J Water Pollut Treat. 1(2):18-26, doi 10.15764.

15. Richana N, Lestari P, Chilmijati N, dan Widowati. 2000. Characteristics of starch (Garut and Sago tapioca) and Utilization into Liquid Glucose. Inside: Indonesian Food Technology Association (PATPI), editor. Empowering the Food Industry in the Context of Increasing Competitiveness in Facing the Era of Free Trade. Food Industry Seminar. Surabaya: PATPI, 396-406.

16. Ahmad F B and Williams P A, 1998. Rheological Properties of Sago Starch. J. Agric Food Chem. 46(1): 4060-4065

17. Chavalparit O, Ongwandee M., 2009. Clean technology for the tapioca starch industry in Thailand. J. Of Cleaner Production, 17, 105-110

18. Sritoth K, Pitachomkwan K, Wanlapatit S, Oates CG., 2000b. Cassava starch technology: the Thai Experience. Stach/Starke, 52, 439-449

19. Usubharatana P and Phungrassami H. 2015. Carbon Footprint of Cassava Starch Production in NorthEastern Thailand. Procedia CIRP 29, 462-467

20. Nemecek T, Kagi T, Blaser S. 2007. Life Cycle Inventories of Agricultural Production Systems. Vol. 15.

21. Wurdinger E., Roth U., Wegener A. \& Peche R. (2003) Kunststoffe aus Nachwachsenden Rohstoffen: Vergleichende okobilanz fur Loose-fillPackmittel aus Starke bzw. aus Polystyrol". Final report. BIfA, IFEU, Flo-Pak (eds.), Projektforderung: Deutsche Bundesstiftung Umwelt; Augsburg, Marz 2003, pp. 514. 